\title{
Human Resource Management is a Prerequisite for Enhancing the Quality of Higher Education in Kosovo
}

\author{
Shqiponja Nallbani PhD Cand. \\ Universiti AAB- Prishtinë \\ shqiponja.nallbani@universitetiaab. edu 1
}

\begin{abstract}
Given its problematic past, Kosovo's economic and social development and its current resolve for a European integration process, will be a challenge that will follow for a long time. Because of the burden that state institutions carry in this mission, it is easily verifiable that the process of reform of public administration staff, both at local and central level, is failing. This is primarily because their number is too large and the government has no plans to either reduce this number or to increase their capacity and competence through educational programs of higher education. So far, the Kosovo government, specifically the Ministries of Education, Social Welfare, Labor, etc., and the local governments have no plans on how to achieve this task and the providers of higher education have not provided any program that would adequately enable employees to get re-qualified, in order to carry out their public duties more efficiently and professionally. Therefore, the requalification of staff at a higher education level is one of the essential factors that should be implemented immediately.
\end{abstract}

\section{Keywords: Requalification, education, public administration, learning programs}

JEL: I2; 125; 130; J2; J24

\section{Introduction}

The role of human resources in a healthy economic growth is already established and is one of the basic elements for an economic growth that is sustainable and fast paced. Human resources are particularly important for countries in transition, as they are reforming their economic concept into market economies. While in the early stages progress towards a market economy depends on the willingness and commitment of the government to implement reforms, development in the later stages of such economies depends largely on the ability of human capital to acquire and use skills needed to build competitiveness in the economy. But not all countries have been successful in getting employees, inherited from the previous socialist system and the transition period, prepared to face the new challenges of globalization.

This paper, in the first part, provides a short overview of the role that state administration staff have had in different periods of time. The meaning of a public official has been explained, as it pertains to the old mindset, which is linked to the possession of public authority by the monopoly holder of state power. Special emphasis is given to the difference in meaning of employees in a socialist system to the ones in a modern democratic state, by identifying the strengths and weaknesses of both systems.

In the context of the current process of institutional qualification, the role of the Kosovo Institute for Public Administration (KIPA) has been discussed. The function of this institute is emphasized, which is to contribute to building a modern public

\footnotetext{
1 The author is a teacher at the University "Haxhi Zeka" - Peja, Kosovo and PhD candidate at the European University of Tirana, Tirana, Albania 
administration in Kosovo, ready to help the overall development of Kosovo as a condition for European (international) integration.

Notwithstanding the role and function of the institute to train public administration staff, this paper demonstrates the fact that the state administration, both at central and local levels, does not respond to the needs for social and economic development and European integration. To eliminate such deficiencies, it is proposed that institutions should find mechanisms for measuring the performance of the civil service and on this basis to coordinate activities with higher education providers in the country to start the phase of professional and scientific requalification of the staff. The implementation of this process will be influenced by institutional needs and carried out by providers of higher education through modern academic modules and programs.

The application of this model, for the requalification of employees, will be a prerequisite for sustainable economic development, societal and social stability, for effectiveness in designing and implementing development strategies and the overall contribution to the country's easier integration process into the European Union.

\section{The role of public administration staff in the modern era}

The role of public administration staff has continuously changed throughout history. According to the older mindsets, government staffs were identified as members who exercised political power. Therefore, the public official was one of the holders of the state power monopoly, or later in a more moderate form, the holder of the authorization who indirectly exercised this monopoly. The concept of the authority to exercise a public servant function in the classic sense in most of its aspects does not change from the post-classic ones. This is because such employees performed specific public tasks legally on the basis of the political power from which state and monopoly of physical violence derived. 1

Although we still notice remnants of the old notions of administrative services, such that are perceived as power or privilege, in the concept of a modern world prevails the belief that public administrative services are a social function that is a useful and a needed mechanism, i. e. community, for the country. The professionalization of state administration staff has certainly helped to create new values such as efficiency, effectiveness and merit, which are important elements found throughout the system that have become basic criteria for acceptance of new employees in the public service progressively. The idea of rewards, according to their skills, has fundamentally and directly changed the professionalism and effectiveness of public administration. As such, today there is indisputable certainty that the system of public administration based on a merit system is considered a mechanism of neutrality in the context of good governance. A number of post-communist European countries, for the purpose of reforming the public administration, are led to implement this process through various changes in the civil service legislation and through ideas supporting professionalism and the merit principle.

The transition period in these countries is likely to be completed by strengthening the nomenclature structure in order to create a new and more advanced system of public services. This is not easily achieved, in the contrary. Former socialist countries of Eastern Europe are characterized by strong public administration; all this as a result of the one-party political system, characterized by a stable leadership force. The first changes towards a market economy and the establishment of a multi-party political system weakened and made politically unstable precisely this important segment of the state. This was reflected by the frequent political changes that resulted in frequent replacements of senior administration officials from the party that lost power from the government or winning coalition, who then applied aggressive differentiation and have no regard of the performance, qualification and quality of staff. Post-socialist countries must still make substantial changes in the general public policy, regardless of political affiliation of public staff. At the same time these changes must be accompanied by a strong political leadership that has sincere willingness to implement reforms. This can be accomplished through the creation of a complex system of education, training and requalification of civil servants and build institutions that will be able to gradually transform into a democratic social order. ${ }^{2}$

\footnotetext{
1 Gabrielian, V. (1999.) Post-communist bureaucracies: organizational modes of transition. International Journal of Public Administration, 22(1):39-68.

2 Goetz, Klaus H., Wollmann, H., (2001.) Governmentalizing central executives in post-communist Europe: a four-country comparison. Journal of European Public Policy, 8(6):864-887. 
It is quite normal that this is not possible to occur the same way in all countries or all municipalities. However, despite their political, administrative, financial or other approach, all are convinced that joint actions to reform the current system of education, training and requalification of civil servants are inevitable. Each of these countries based their approach in a clear particular tradition, value system, geographical environment and a number of other factors in order to implement their goals. In general, universities, schools and other institutions with programs dealing with public administration have spread rapidly the need for lifelong training and development to employees. Certainly, changes in this important segment are contingent upon the interest for integration in the European Union. The process of public administration reform in Kosovo should not be seen as separate project from other areas of the EU accession process. This is a common task of the process for furthering the European agenda. At the same time, public administration reform has to do with improving the quality and manner of delivery of public services to citizens. Better coordination of policies, independence of oversight institutions, better training of senior public administration staff, educational requalification, implementation of several major laws on civil service, are all an indispensable necessity without which there is no future. ${ }^{1}$

\section{The current institutional qualification process}

Kosovo, as most countries of South Eastern Europe, has tried to devote a significant place in its reform process to the qualification of civil servants involved in public administration. The Administrative Regulation No. 2001/192 and Administrative Direction ${ }^{3}$ implementing this regulation, established the Kosovo Institute for Public Administration (KIPA). This institute was established as an executive agency within the Ministry of Public Administration. KIPA aims to contribute to building a modern public administration in Kosovo, ready to help the overall development of Kosovo as a prerequisite for European (international) integration. KIPA is ready to serve the training and development needs of the public administration through a qualified staff, cutting-edge training technology and a rich library. The overall goal of KIPA is to support the Government of Kosovo, the Kosovo Civil Service, working on training public administration staff through quality training programs in accordance with European public administration standards. KIPA aims to be an institute of international standards in terms of operation, structure, policies, accountability and capacity to train and develop the Kosovo Civil Service. Kosovo Institute for Public Administration (KIPA) is a government institution established for the purpose of training civil servants and increasing the sustainability of the Kosovo Civil Service (KCS) in order to develop and increase the quality of the civil service that the Kosovo public administration offers. KIPA's activity focuses mainly on: identification of training needs in the civil service, design and development of training programs, coordination of various projects for capacity building in KCS, dissemination and exchange of new knowledge for the public administration, and professional research for new developments in the public administration. The entire activity of the agency focuses on the areas of human resource training, legislation, budget and finance, information technology, municipal affairs, general administration management. ${ }^{4}$

\section{Which path should Kosovo take to advance education among public administration staff}

Frankly speaking, what the Kosovo Institute for Public Administration (KIPA) has done so far in Kosovo is not encouraging. All national and international reports on the situation in the country emphasize that this public service is not professional, it is minimally efficient and very cumbersome. Although this is not explicitly stated by Kosovo's governing institutions, it is clear that the Government, specifically the Ministry of Public Administration, has engaged FRIDOM ${ }^{5}$ as a specialized mechanism to professionally conduct a functional review in the horizontal and vertical plain of the central government, local governments and the entire state administration. Since we are in this undesirable situation then the question arises which path should Kosovo take in order to have a quality solution to this issue. Should a model be identified and borrowed from other countries or is it better to seek solutions based on the historical, political, economic and social circumstances?

\footnotetext{
1 Goetz, Klaus H., Wollmann, H., (2001.) Governmentalizing central executives in post-communist Europe: a four-country comparison. Journal of European Public Policy, 8(6):864-887

2 UNMIK Regulation No. 2001/19 on the Executive Branch of the Provisional Institutions of Self-Government in Kosovo, issued by the Special Representative of the United Nations in Kosovo - based on UN Resolution 1244

${ }^{3}$ Administrative Instruction No. 2003/25

${ }_{4}^{4}$ For more information please refer to: http://ikap.rks-gov.net

5 FRIDOM is a project of the Government of the Republic of Kosovo, based at the Ministry of Public Services. Its activities are financed by DFID of Great Britain and assisted by the international consortium comprised of Tribal HELM (UK), CPM Consulting Group (LV), Governance Institute (SK) and Altair Assessors (SP).
} 
The answer to this question is not easy, nor can it be exclusive. The experiences of other countries, whether positive or negative, are always helpful. The legislation and institutional structures should not simply be copied automatically, as it usually happens to us, but whatever is recommended, within the context of the local circumstances and realistic possibilities, attention should be given to the possibilities that offer a better solution. It is clear that any country that may be taken as a model does not have a perfect system. Almost all other post-communist countries have not yet solved the problem of insufficient education and/or insufficient training of administrative staff for new tasks that require market-oriented skills and take account a multiparty political system and the globalization of the world. We can see that Hungary, Lithuania and Slovenia in certain segments have recovered the training and requalification of staff and are now far ahead of Kosovo. Eg. Such experiences should be used towards continuous efforts to improve the perceived legal shortcomings and failures and to further the development of human resource management. This approach is the safest and should be followed by effective dynamics. This is because their approach has proven to be successful, which is a necessary requirement for obtaining a positive opinion regarding the fulfillment of the conditions for EU membership.

To sum up the situation in our country, it can be said that Kosovo does not have a comprehensive system of education to serve the administration. Educational programs in the field of public administration are only partially carried out in secondary schools and colleges, while such programs in higher education are lacking. School curricula provide administrative leadership classes from one to three years in secondary economic-legal vocational schools in almost all cities of the country. Meanwhile, undergraduate BA degrees from this sector are offered at the University of Prishtina - Faculty of Philosophy Department of Administration and at several private colleges. Although administrative studies curricula have formally been streamlined a few years ago, the contents in essence exclude or ignore subjects from the technical side of economics, economic policies, sociological approaches, and even constitutional cases. The lack of a study process, which after completed does not provide a university degree, hinders employees to continue their education in this field. It is also not possible to enroll in graduate studies pertaining to this field.

It is our conclusion that if Kosovo wants to achieve its goal of joining the European Union, it should have the administrative capacity regulated in line with European standards. At the level of the education system, it is necessary to establish a UNIVERSITY of public administration offering a multidisciplinary and modern program and curricula harmonized with the highest administrative needs. People with university degrees, master or doctorate, in public administration must be placed in accordance with their knowledge and get the appropriate number of management positions in public administration. It is also necessary to establish a legal framework for the establishment of training and development institutions at central, regional and local levels. In terms of organization, it is desirable to create a separate system of work/or administrative departments within the organization to deal with issues such as human resource management and to work closely with the center. This however, should be just the beginning. The centers for education and training must continuously develop high quality and effective programs in cooperation with scientific institutions. With regards to the context, these programs cannot remain at the current level of teaching foreign languages or providing basic computer skills. Staff needs to be prepared through the development of different types of programs tailored to individual task groups and bespoke to the needs of institutions and administrative categories. For example, the head of the central administration, the higher education specialist in a particular region and the administrative officer of a municipality should not get the same training program and/or training course. Finally, the officers and the obligation to motivate training and development throughout their career and to provide funding in the budget for that purpose.

The institutional changes in the public administration system, conditions required of all EU candidate countries, are not contrary to the interests of Kosovo. Part of such a reform would be the transformation of certain parts of the social or economic system. Efforts to professionalize the civil service system and the creation of an education and training system carried out by Hungary, Lithuania, Slovenia and other countries in transition, were beneficial in many ways and should be studied and adopted from our side as well. The advancement of social organization must be achieved in any form, even if the country cannot be part of the EU. It is mandatory that public works in administration should be accomplished thorugh professional management. This enables management techniques to be perfected, reduces economic, social and environmental problems and minimizes the uncertainties of a current and future politicized, incompetent and ignorant administration and officials who have nothing to do. 


\section{The role of higher education providers in the requalification of public administration staff}

Earlier we mentioned that the structure, the ability and willingness of public administration staff in our country leaves much to be desired. This section is intended to highlight the issue of high-level employees in the public administration who have superior qualifications that they gained prior to the 90ties of the previous century. According to the analyses taken from the FRIDOM ${ }^{1}$ reports, the number of employees falling in that category is large. It is true that a large number of them have been exposed to a series of training courses organized by the Kosovo Institute for Public Administration (KIPA), but their professional performance is insufficient for them to successfully fulfill their duties. In addition to institutional training, we consider that respective ministries should draft a project that would allow for cooperation with higher education providers to prepare academic learning programs for the purpose of re-qualifying such employees under the principle of "lifelong learning"2.

The field of education and training, according to this principle, should be considered as one of the highest political priorities of Kosovo, as a country that claims to be part of the European Union. The idea of lifelong learning (LLL) was developed for the purpose of supporting and improving the international competitiveness of Europe. Also, the requalification of public administration staff is entirely compatible with such principles and is precisely the point where modern concepts coincide. Such employees should be aware of the level of knowledge and skills they possess in relation to needs and should be equally vigilant and be able to deal with global economic requirements, and find their way in a knowledge-based society. This is especially true in the labor world. Continuous professional education and on-the-job trainings are needed for both the individual worker and the European economy in general, particularly in relation to international competition (see the EU Lisbon strategy). Furthermore, those who continually strive to improve their knowledge, skills and competencies also develop their personality in many ways. In return, they allow themselves greater participation in society. Therefore, lifelong learning is a pillar of democracy. Lifelong learning uses teaching and training methods that meet the specific needs of adults. A fundamental approach is making use of the skills that learners already possess. Based on this, the responsibility to perform these tasks lies with:

The central government, ministries and ultimately relevant local governments must have a clear plan for their needs regarding professional human resources for the segment of public administration. These needs should be analyzed based on strategic development documents. Analyzing the performance of human resources for each department and identifying the needs, i. e. using a SWOT program, will create a realistic picture of the situation and allow for the extraction of relevant information indicating where the needs for intervention exist.

Institutions must work towards increasing the level of awareness of staff, working in every level of public administration, of the need for requalification and specialization to meet the needs of economic and social development.

Providers of higher education, in cooperation with the central government, ministries and local governments, for the purpose of re-qualifying this category must develop:

Standardized programs for re-qualifying staff that have higher education diplomas, two years with the provision of materials and information on modern approaches in the field of social sciences, economics, legal, information technology, and particularly in foreign languages and public administration management. The program, as needed, can be offered in two modules from 60 ECTS up to 120 ECTS ;

Supplementary programs with courses that provide information on modern social, economic and legal approaches as well as administrative management, which for an academic year shall not exceed 60 ECTS.

\footnotetext{
${ }^{1}$ FRIDOM is a project of the Government of the Republic of Kosovo, based at the Ministry of Public Services. Its activities are financed by DFID of Great Britain and assisted by the international consortium comprised of Tribal HELM (UK), CPM Consulting Group (LV), Governance Institute (SK) and Altair Assessors (SP).

2 When planning for a year, plant corn. When planning for a decade, plant trees. When planning for life, train and educate people. Chinese proverb, $650 \mathrm{BC}$.
} 
Specialized professional programs for training administration staff in specific areas, i. e. managing the development of tourism by providing programs in the field of tourism, economics, environmental studies, foreign languages, project management, management basics, etc.. Such programs are likely to contain up to 90 ECTS.

Master programs for preparing administration staff in specific areas where their role will be focused on analytical project work and project development to meet the needs of certain segments of the social and economic life. The program should provide quality information especially in the field of scientific management and subjects related to econometrics.

Providers of higher education, that are accredited institutions, are considered to have the capacity and the required sensitivity to review and adapt programs and ECTS modules according to the needs of the above-mentioned institutions and according to the social needs, to ensure that staff requalification that is efficient, modern and quality service based on European Union requirements.

It is exactly this combination of the social need for skilled employees in the public administration, the contribution of higher education providers and the recommendations of the European Union Commission that are firmly related in the legal, economic and academic plain together with the Bologna Declaration, the European Qualifications Framework ${ }^{1}$, the White Paper of the EU and the spirit of the country legislation.

\section{Conclusions}

In its simplest meaning, this paper has considered that the Public Administration represents a combination of politics with bureaucracy, political power with administrative skills, policy and decision making with influencing factors, public with private. It simply represents a mix between processes, individuals, organizations, authorities, which connect with each other to advance the public/private interest, the drafting, management and implementation of policies and action programs in accordance with the laws and regulations in effect. It is evident that public administration is important for any society for the fact that it represents an indivisible element of the life of an individual, group, society, and country. Much like an individual manages his or her potential, capacity, and life, so do the group, society, and state administer their own. There is no society or state without the public dimension. In the political context, Public Administration encompasses the structure, function, character and relationship between central and local government, clashes and regulation between public and private, the system of administrative and political values underlying society in general, and political society in particular, or the relation between society, government, policy-makers and knowledge. In the organizational context, Public Administration involves human relationships within organizations, the decision-making culture, the character of leadership and policy-making, and challenges of group interactions. From the managerial context, Public (and also private) Administration includes challenges such as management of human and material resources, the budgeting process, the policy-making process, and the regulatory role of the government. Finally, seen in the context of relations between public administration and social changes, Public Administration has to do with the democratic character, or the lack of it, in relations within the administration itself, between administration and political policy-makers, between acceptance and rejection of changes that permeate society.

Most post-socialist countries have established by legislation centers or institutes that have assumed the role to enhance the efficiency and effectiveness of public administration staff through continuous training. UNMIK, in 2003 established the

\footnotetext{
1 The National Qualifications Framework is an important component within the system to reform education and training in Kosovo. The goal is to improve access to employment and further learning, ensuring that qualifications are consistent with job requirements, to meet the demands of students, the economy and education and training institutions. NQF will support the development of quality improvements in education and training qualifications which are based on international comparable standards of knowledge, skills and competencies supported by rigorous quality assurance. By providing a transparent system of national qualifications, by clarifying the nature of the qualifications, the connection of the qualifications and by providing a basis for attainment across all parts of the education and training system, NQF will support progress and mobility for lifelong learning, through education and training pathways. A flexible learning, focused upon the need of the individual for employment, will provide increased opportunities for recognition of prior learning, access to assessment and certification. It is important that NQF will provide a basis for cooperation and mutual understanding between the NQF and the European Qualifications Framework (EQF). The White Paper on the preparation of the Associated Countries of the Central and Eastern Europe for Integration into the Internal Market of the Union (Adopted by the European Council in Essen in December 1994) which regulates the mutual recognition of professional qualifications, p. 403 / Published by: Ministry of European Integration of the Republic of Albania - Prepared for publication by: Center of European Documentation and Information. ANNEX Published by the European Commission, COM (95) 163; May 1995
} 
Kosovo Institute for Public Administration (KIPA), an institution that was created as an executive agency within the Ministry of Public Administration. KIPA aims to contribute to building a modern public administration in Kosovo, ready to help the overall development of Kosovo as a prerequisite for European (international) integration. KIPA is ready to serve the needs for training and development of the public administration through a qualified staff, cutting-edge training technology and a rich library.

Despite the existence of such centers, it is concluded that the public administration of the country is not only large in numbers of employees, but as such it is not professional and is a hindrance to economic and social development. To eliminate this defect, it is proposed that central and local institutions undertake certain measures pertaining to the identification of performance of these employees and through a SWOT analysis to identify urgent needs they have, so that existing human resources be re-qualified.

Furthermore, the process of retraining of employees is proposed to be implemented by higher education providers in the country who are already accredited. These institutions need to design and accredit specific programs depending on the needs of the institutions, by offering modern modules that contain knowledge, language and information that will make public administration staff more efficient at their work, based on the skills and competencies they acquire.

\section{Bibliography}

Brejc, M. (2002. ) Slovenia. Evaluation of academic programmes in the field of public administration and their degree of europeanisation. Bratislava: The Network of Institutes and Schools of Public Administration in Central and Eastern Europe (NISPAcee). Published on 10. 3. 2005. on website NISPAcee: http://www. nispa. sk/reports/Slovenia/Slovenia. htm

Farazmand, A. (2002. ) Administrative ethics and professional competence: accountability and performance under globalization. International Review of Administrative Sciences

Gabrielian, V. (1999. ) Post-communist bureaucracies: organizational modes of transition. International Journal of Public Administration

Goetz, Klaus H., Wollmann, H., (2001. ) Governmentalizing central executives in post-communist Europe: a four-country comparison. Journal of European Public Policy,

The Kosovo Higher Education Development Strategy (2005 - 2015)

National Qualification Framework - http://www. akk-ks. net/kkk/korniza-kombetare-e-kualifikimeve

LICENSING AND ACCREDITATION UNDER THE LAW ON HIGHER EDUCATION IN KOSOVO 2002 - 2009 - Steve Bristow report on Licensing and Accreditation according to Kosovo Law on Higher Education 2002 - 2009

Al: No. 02/2013 on Accreditation of Higher Education Institutions in the Republic of Kosovo

Al No. 14/2013 Teacher Performance Assessment

Al - The criteria on licensing private educational institutions at primary and lower secondary and upper secondary vocational training institutions 2011-2012 